\title{
TOWARDS KINETIC REGIME OF REVERSE FLOW OPERATION
}

\author{
Yogi W. Budhi \\ Program Studi Teknik Kimia, \\ Kelompok Keahlian Perancangan dan Pengembangan Proses Teknik Kimia \\ Fakultas Teknologi Industri, Institut Teknologi Bandung \\ Jl. Ganesha No. 10, Bandung 40132 \\ E-mail: Y.Wibisono@che.itb.ac.id
}

Submitted 10 Oktober 2005, reviewed 15 Oktober 2005, and accepted 27 Desember 2005

\begin{abstract}
An analysis of reverse flow operation and its experimental study for ammonia oxidation to produce either $N_{2}, N_{2} \mathrm{O}$, and $\mathrm{NO}$ have been carried out. An experimental set-up of reverse flow reactor was constructed for a laboratory scale. The experiment under steady state operation was performed as a base case in order to judge the potential during the reverse flow operation. Aim was to investigate the behavior of reverse flow operation and to observe the reactor performance. Focus was on the comparison of the steady state and reverse flow operations. The experiments show that the behavior of reverse flow reactor is strongly influenced by the ratio of the switching time over the residence time. The ammonia conversion during the regular reverse flow operation shows lower values compared to the steady state operation, which is even worse during asymmetric mode. The product distributions may change under flow reversal, depending on the operating conditions, regime of operation, and operation mode.
\end{abstract}

Keywords: Reverse Flow Operation, Fixed Bed Reactor, Selectivity Manipulation, Steady State Operation, Ammonia Oxidation

\begin{abstract}
Abstrak
Sebuah analisis operasi aliran bolak-balik dan studi eksperimental oksidasi amoniak untuk menghasilkan baik $N_{2}, N_{i} \mathrm{O}$, dan NO telah dilakukan. Sebuah perangkat eksperimen reaktor aliran bolak-balik dikonstruksi untuk skala laboratorium. Eksperimen dalam operasi keadaan tunak dilakukan sebagai kasus dasar untuk menilai potensi operasi aliran bolak-balik. Tujuan penelitian ini adalah untuk meneliti kelakuan operasi aliran bolak-balik dan untuk mengamati kinerja reaktor: Kajian ini dititikberatkan pada perbandingan operasi keadaan tunak dan operasi aliran bolak-balik. Hasil percobaan menunjukkan bahwa kelakuan reaktor aliran bolik-balik sangat dipengaruhi oleh nisbah waktu pembalikan arah aliran (switching time) terhadap waktu tinggal. Konversi amoniak dalam operasi aliran bolak-balik menunjukkan nilai yang lebih rendah dibandingkan dengan operasi keadaan tunak, dan dalam mode asimetrik konversinya bahkan lebih rendah lagi. Distribusi produk dapat berubah dalam pembalikan aliran yang bergantung pada kondisi-kondisi operasi, daerah operasi, dan mode operasi.
\end{abstract}

Kata Kunci: Operasi Aliran Bolak-balik, Reaktor Fixed Bed, Manipulasi Selektivitas, Operasi Tunak, Oksidasi Amoniak 


\section{Introduction}

Transient operations open a breakthrough in the process intensification, which may offer considerable advantages for the process performances if a dedicated procedure can be developed (Budhi et al., 2004a). In the case of heterogeneously catalyzed gas reactions, such artificially invoked transient behavior provides opportunities to create dynamic changes of the catalyst surface coverage, which affect the rates of the catalytic reactions (Budhi et al., 2004a). In particular, periodical variation effects of the inlet concentration and the flow rate in the reverse flow reactor for the treatment of polluted air was investigated by Cittadini et al. (2001). Significant effects on the maximum temperature and outlet concentration were found. Moreover, a novel concept of temporarily lower feed concentration before switching the flow direction was conceptually studied by Budhi et al. (2004a) and was experimentally performed by Budhi (2005) for a reverse flow reactor.

Among the various preferences for periodic operation, reverse flow reactor offers the combined benefits of a permanent unsteady-state regime and a constant time-averaged regime. Reverse flow reactor (hereinafter referred to as RFR) might be defined as a fixed bed reactor in which the flow direction is periodically alternated at certain switching time. It has not yet been widely applied for improvement of conversion or selectivity, but was shown beneficial for exothermic reactions from a viewpoint of energy saving (Boreskov et al., 1982; Boreskov and Matros, 1983; Matros and Bunimovich, 1996).

Figure I represents a simplified process scheme of the reverse flow reactor. During the first half of each cycle, the flow passes through 1-2-R$3-4$, and during the second half of each cycle, the flow passes through $1-2^{\prime}-\mathrm{R}-3^{\prime}-4$. In most reverse flow operation (hereinafter referred to as RFO) cases, the catalyst acts not only as a chemicalreaction booster, but also as a heat sink necessary for accumulating energy from the exothermic reaction due to the fact that the heat capacity of the catalyst bed is much higher compared to that of the processed gas. In this respect, the catalyst bed eventually provides a periodic heat exchange between the stored energy and the cooler feed gas (Matros and Bunimovich, 1996). The advantages of the so-called forced transient operation have been highlightened and enumerated some decades ago. The concept of RFO was refined and subsequently extended to catalytic reactors by Boreskov et al. (1982). The Use of the reverse flow principle as transient operation procedure for a catalytic reactor

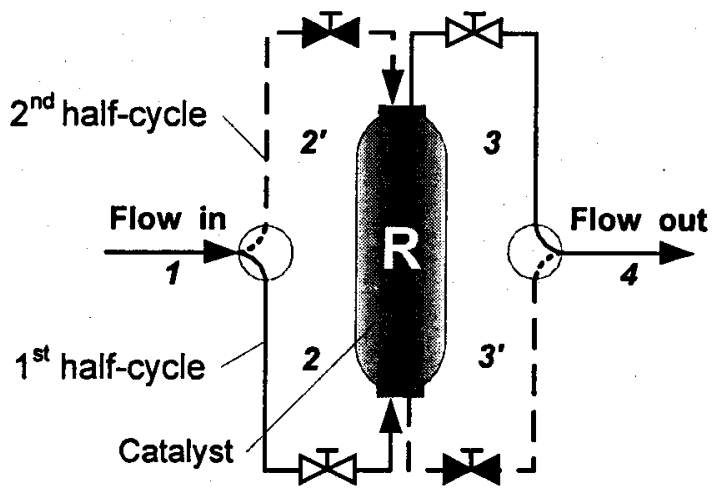

Note: The solid lines show active flow, while the dashed lines show inactive flow

Figure 1. Principle Diagram of Reverse Flow Reactor

Becomes interesting by the combination of dynamic properties at a microscale (catalyst) and at a macroscale (reactor). It may produce more favorable concentration and temperature profiles for the catalytic process (Ferreira et al., 1999).

In particular, periodic flow reversals provide a way to affect the surface coverage of catalytic sites. In the case of non-linear kinetics, changes in conversion or selectivity could be expected when compared to once-through operation (Budhi et al., 2004a). If the catalyst is operated under unsteady-state conditions, it is therefore possible to attain such a state, gas composition, and structure that would allow a noticeable increase in the selectivity and productivity of a process. Unsteady-state operation allows the processing of reaction gases with both constant and varying inlet parameters (Boreskov and Matros, 1983).

The selective oxidation of ammonia $\left(\mathrm{NH}_{3}\right)$ to produce either nitrogen $\left(\mathrm{N}_{2}\right)$, nitric oxide $(\mathrm{NO})$, or nitrous oxide $\left(\mathrm{N}_{2} \mathrm{O}\right)$ was chosen as a model reaction due to its various reaction products, which are inline to selectivity issue. The primary goal is to demonstrate that reverse flow operation may create dynamic changes of active site coverages, which might change the conversion and selectivity from the steady state, once-through operation. The effects of switching time, duty cycle, ammonia concentration, gas residence time, and time period of lower feed concentration are illustrated.

The selective oxidation of ammonia on $\mathrm{Pt}$ catalyst supported by $\mathrm{Al}_{2} \mathrm{O}_{3}$ is a very exothermic reaction. In this work, it was taken as a model reaction due to its possibility to play around with 
the product selectivity, particularly by applying the concept of reverse flow operation. The catalyst concentration used in this experiment was very low in order that the competition of reaction rate and switching the flow direction within the similar order of time scale that can be realized by the solenoid valves. Most crucial parameter to significantly influence the conversion and selectivity is the ratio between the switching time and the gas residence time.

\section{Fundamental}

The analysis of the reverse flow reactor behavior was based on the mathematical modeling and simulation. All simulations were performed with an imposed symmetrical temperature profile to assure that thermal behavior is in relaxed steady state regime compared to the dynanics of the mass balance (Budhi et al., 2004a). The concentration profiles as function of time generally show stable oscillations after three cycles, which supports the earlier suggestion that the dynamics of the mass balance are much faster than those of the energy balance. Therefore, a steady temperature profile can always be imposed, once the proper function is known. It should be noted that a temperature profile could be directly measured during experimental work in reverse flow reactors. For low feed concentrations and/or low conversion, isothermal reactor operation will be achieved, which means that model validation can be performed with a relatively uniform reactor temperature.

The steady state results were inspected with respect to the occurrence of pronounced axial profiles of gas phase concentrations and/or catalyst surface coverages. Conceivably, such behavior is most likely affected by applying reverse flow operation. Reverse flow simulations were therefore performed at conditions that give rise to pronounced axial profiles.

Apart from the three process variables: temperature $(T)$, residence time $(\tau)$, and feed ratio $(F R)$, that characterize the steady state, one needs a new parameter, defined as the ratio of switching time $\left(t_{s}\right)$ and residence time in order to clearly define RFO conditions. As mentioned elsewhere (Budhi et al., 2004a), the time scale of the switching time for the application of reverse flow operation for selectivity manipulation is completely different when compared to the similar operation for energy saving. For the latter, the switching time is quite large, in the range of several minutes to several hours (Bunimovich et al., 1995). In the current application, the time scale of switching has the same order of magnitude as the residence time (seconds). It should be noticed if such high switching frequencies could be realized in industrial practice. The performance of the fixed-bed reactor with periodical flow reversal is dependent on many design parameters, such as reactor length and overall bed porosity, as well as many operating parameters, such as feed concentration, gas flow rate, and flow switching frequency (Salinger and Eigenberger, 1996a).

The cycle duration time scale, defined as the time required for a heat wave to pass through a bed, is typically several minutes for high-pressure processes to several dozens of minutes for $\mathrm{SO}_{2}$ oxidation. If the reaction steps or side processes defining the catalyst state dynamics occur on a time scale comparable with the cycle duration, then the catalyst state will be substantially nonsteady (Bunimovich et al., 1995).

In the application of reverse flow reactor for energy saving, it is necessary to know the dependence of the maximum bed temperature on the operating conditions and kinetic parameters to prevent catalyst deactivation and undesirable side reactions. Nieken et al. (1994) found that the maximum temperature was rather insensitive to changes in the switching frequency when a firstorder, irreversible reaction occurred in a reactor with no inert section. Two limiting cases were considered, i.e. very low and very high flow reversal frequency. In the low switching case, the temperature front moves downstream at a constant shape and velocity. In the high switching frequency, first considered by Matros (1989), the solid temperature profile remains essentially stationary due to its very high heat capacity relative to that of the gas. When the switching frequency is very low, the reactions may be completed either in a temperature front moving at a constant velocity and shape, or in two consecutive temperature fronts separated by an almost constant temperature plateau with upper front moving faster than the lower one (Somani, 1997).

The time scale of flow reversals, necessarily for manipulation of the selectivity, appears in the order of seconds, which is significantly smaller than the order of minutes, used in the classical reverse flow application for energy saving. It means that manipulation of the reactor selectivity requires considerably more frequent flow reversals due to the need for the competition with the reaction rate. If the reaction rate is faster than the time scale for reversing the flow direction, then there is a steady-state limitation. If an antipode situation exists, then an unsteady-state limitation holds for the system. 
In the terminology of the switching time for manipulation of the catalyst surface coverage, one can distinguish two types of operation mode, i.e. symmetric and asymmetric operations. The

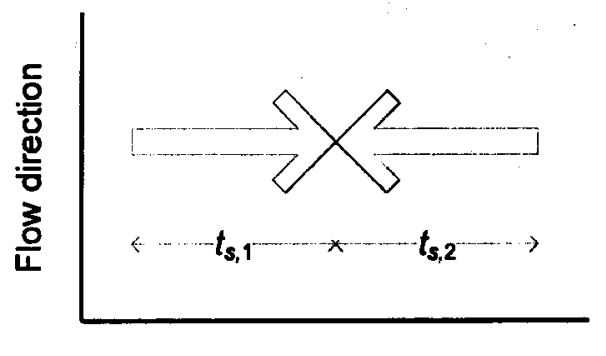

Time symmetric operation occurs when the time periods between two flow-directions (see $t_{s, 1}$ and $t_{s, 2}$ in Figure 2) is similar, otherwise asymmetric operation holds (see $t_{s, 3}$ and $t_{s, 4}$ in Figure 2).

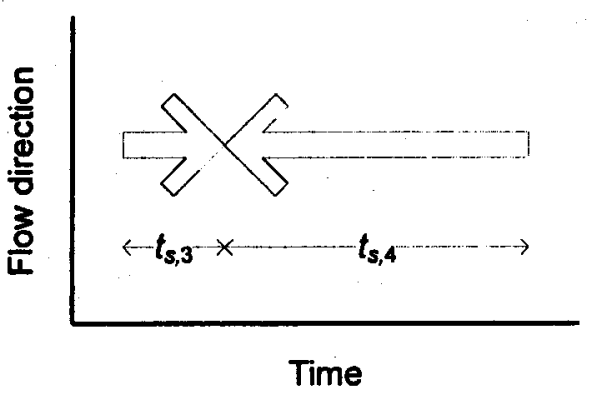

Figure 2. The Schematic View of Symmetric (a) and Asymmetric (b) Operations in The Reverse Flow Reactor

In a very fast frequency of flow reversal, notably at $<1$, a part of gas standing in the center part of reactor becomes a dead gas volume. The existence of a dead gas volume may become interesting for manipulation of catalyst surface coverage. On the other hand, if the dead gas volume cannot provide the necessary coverages to any reaction product, such trapped gas and its existence becomes superfluous and needs to flush in order to generate a new gas and surface coverage compositions. If no flushing mode is actuated, the reaction continues until the limiting reactant is completely converted. To achieve stable oscillations during the reverse flow operation with $<1$, also called high frequency flow reversal, it requires longer time period than low frequency flow reversal.

Figure 3 shows the profiles of the limiting reactant along the reactor between reverse flow operation (RFO) and steady state operation (SSO). The conversion levels of the steady state $\left(X_{\mathrm{sso}}\right)$ are shown by the outlet conversion at $z=1$, whereas conversion during the reverse flow operation $\left(X_{k F o}\right)$ is expressed by the time-averaged value during one-full cycle produced from the active zone only, where the feed gas enters the reactor and the products flow out. Please note if the flushing method is applied, the whole reactor part should be taken into account. The reverse flow operation profile reached after full conversion of the limiting reactant on the prolonged time can sometime be better than steady state operation, or worse, depending on the degree of conversion during steady state. In this case, the active zone becomes a high potential after stable oscillations because in a relatively shorter catalyst lengtb, the limiting reactant reaches its complete conversion.

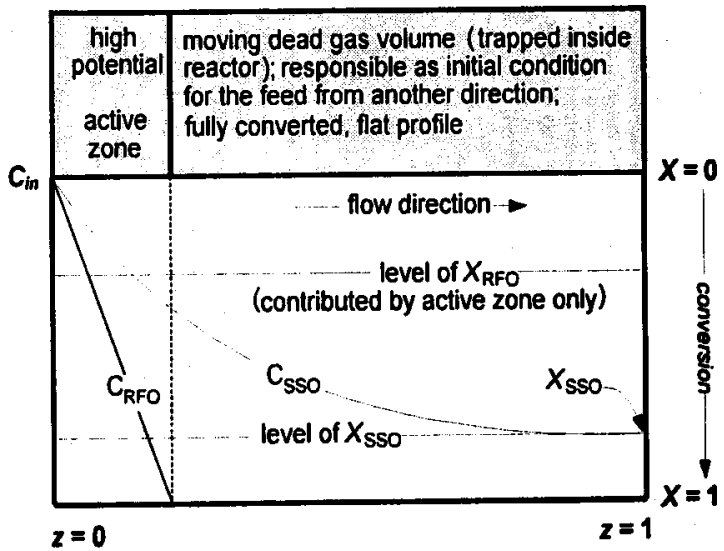

(a)

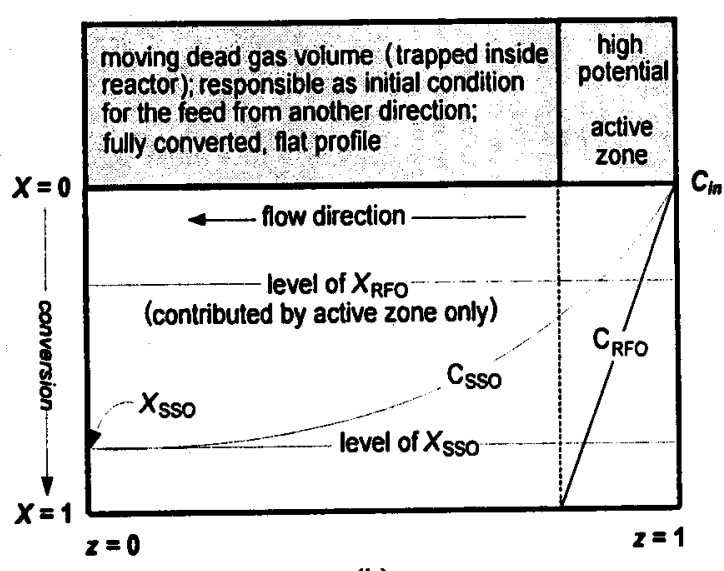

(b)

Figure 3. Reverse Flow Operation with A Dead Gas Volume After Fully Conversion of The Reactant in The Centre Part of The Reactor: (a) forward flow, (b) backward flow 


\section{Methodology}

In order to obtain transient data during reverse flow operation, a dedicated experimental set-up of a reverse flow reactor and online analysis equipment are required. The transient data are obtained by alternating the flow direction from the reactor ends. By the use the same set-up facilities, steady state data can also be obtained by operating the reactor in a unidirectional flow. The steady state data are necessary as a reference for the data obtained in the reverse flow experiments in order to judge if the reverse flow operation can create benefits compared to the steady state operation.

A schematic view of the experimental setup outlined in Figure 4 basically consists of a feed section, a reactor section, and an online gas analysis section. This set-up was designed with fully automated control system. The control system and its associated were built according to a general-purpose electrical classification. The experimental set-up is operated from a computer, which is friendly programmed to control the reactor. This computer is equipped with the dataacquisition cards to allow the data collection. Since the set-up was computerized, opening and closing all solenoid valves at very short switching times (e.g. $1.25 \mathrm{~s}$ ) can be perfectly incorporated. Moreover, with Brooks' mass flow controllers, the flow rate of the inlet gases and their compositions of the reaction mixtures can also be set precisely. $A$ back-pressure controller and pressure-relieving valve were installed in order to avoid the pressure changes in the reactor due to the sudden switching and for the reason of safety, respectively. In the downstream just before the vent, a water condenser was installed to avoid the condensation of water as reaction product. In case of emergency, any critical points those exceed the maximum value were connected to the alarm sensors. A primary shut down key was equipped in the case that failures cannot be precisely handled.

The control system consists of one rack with one communication and several different types of I/O modules. All digital I/O's are done via The National Instrument digital PCI card inside the computer. This is performed to decrease the switching time of some quick acting solenoid valves. All controls are carried out in the computer through the Labview software. The computer system is connected to the Fieldpoint communication module and is used for the Human Machine Interface, data-acquisition, and control.

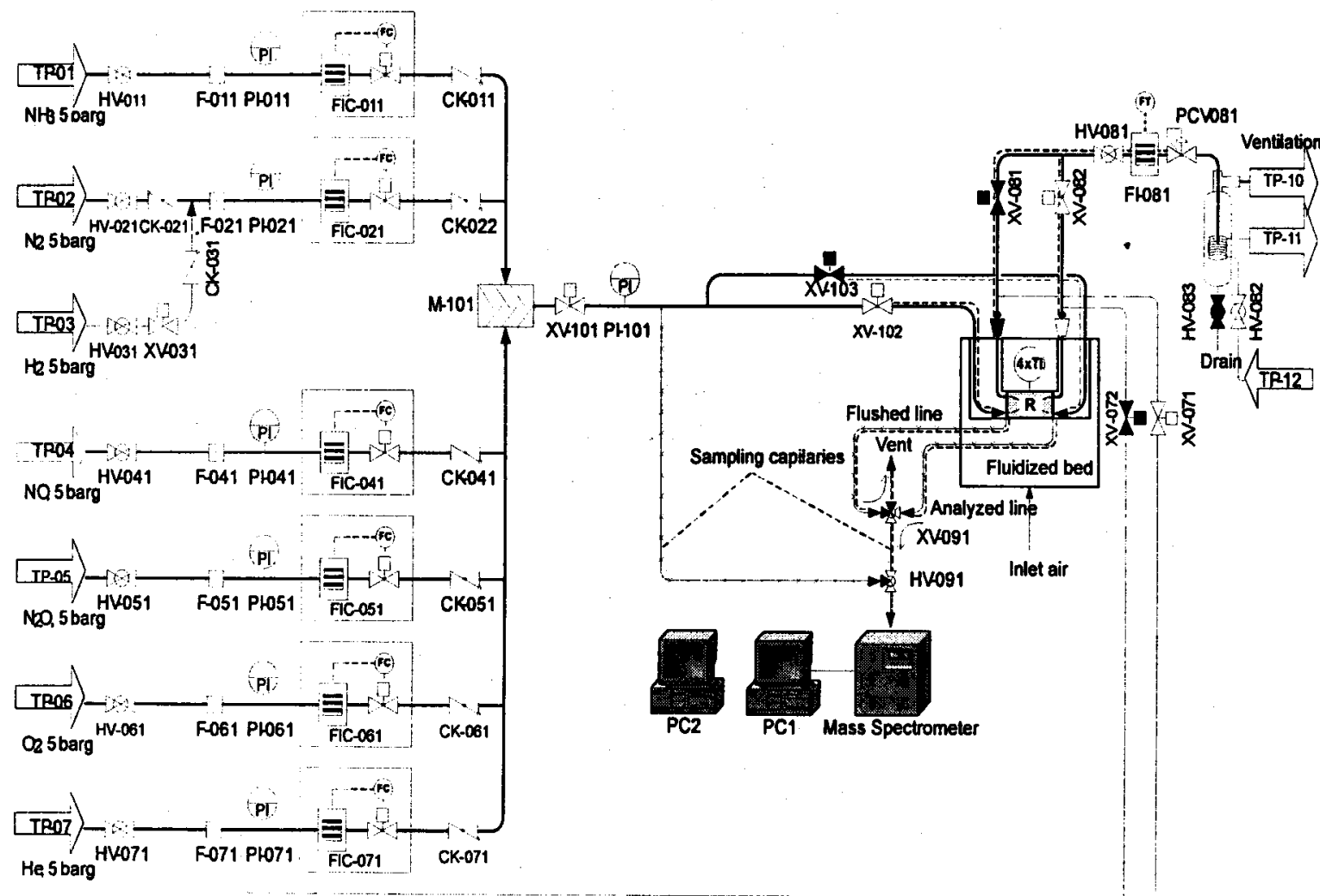

Figure 4. Schematic View of The Experimental Set-up of A Reverse Flow Reactor for Exploratory Scale 
The reverse flow reactor module consists of 4 preheaters, an Incoloy alloy $800 \mathrm{H}$ reverse flow reactor, a fluidized sand bath beater, and two flow lines to the vent beader. The preheaters are required to meet the desired gas flow inlet temperature to the reactor. The reactor is contained in the fluidized sand bath heater in order to easily remove the released by the expthermic reactions and to ensure uniform heat distributions. In addition, the fluidized sand bath heater can heat-up very fast the reactor up to the desired reaction temperature during the start-up. The temperature controls, both inside the reactor and in the fluid sand bath, will always maintain the desired temperature set-points.

The feed line to the reactor is split up into two ways, once for each reactor inlet. Both ends of the reactor can act as an inlet and as an outlet, depending on the flow direction. Two sample chambers, immediately in the reactor ends, are connected via $1 / 32$ " sample lines and the sampling valves to the online mass spectrometer for neal time analysis. Four-point thermocouples allow monitoring of the axial tempenature profile along the catalyst bed to assure isothermal conditions. The verification of temperature distribution is always conducted during the experiment.

The catalytic fixed bed reactor was designed to approach the plug flow behavior in order to avoid mixing of gases along the reactor in the axial direction. The plug flow character is enhanced by using high gas flow rates leading to a short gas residence time (order of seconds). The convection is the only significant transport mechanism in an ideal plug flow reactor. The assumption of plug flow will also facilitate the modeling, which was published elsewhere (Budhi et al., 2004a, 2004b).

Upstream of the roactor; the gas line is secured by an electromagnetic valve actuated by a computer system. The total pressure in the reactor is kept constant at $110 \mathrm{kPa}$. As mentioned, the reactor pressure is controlled by a back-pressuro controller (PCV-081). In the feed lines to the reactor, quick acting solenoid valves to direot the flow are installed. The solenoid valves are placed after the splitting point and before the proheatersin order to avoid damage due to the heating . During the reverse flow operation, the solenoid walves are alternately operated. The time between switches from open to close and vice versa is controllable. For the line where the feod solenoid valve:isopen; the feed gas will flow to the reactor thy pusbing the sapphire bead and releasing an Inconel alloy $X$ 750 spring (both mounted in the reactor inlets) to : an open condition that allow the gas entering the reactor. To prevent gas leakage from the 'not used' outlet, high pressure Helium ( 5 barg) is operated to retain the spring from outward direction.

Four K-type thermocouple tubes ( $3 \mathrm{~mm}$ ) allow monitoring the axial temperature profile along the catalyst bed in order to assure isothermal conditions. All temperature data were collected during the experiment with the frequency of twice per second, runaing on a separate portable computer. Temperature profiles in the axial andtor radial direction of the reactor could have a profound influence on observations, and should therefore be avoided. In practice, a temperature difference along the reactor and between the reactor centre and wall of $5^{\circ} \mathrm{C}$ is allowed.

Prior to the kinetic measurements, about 3.50 gram $0.05 \%$ Pt catalyst supported on $\mathrm{Al}_{2} \mathrm{O}_{3}$ with particle diameter of $106-212 \mathrm{~m}$ was uniformly loaded to the tubular reactor. The catalyst bed was retained by two sintered quartz plates (left-right sides) and gas distributors in onder to enthance radial distribution of the inlet stream. The catalyst bed was prepared in such a way so that the relative pressure drop over the bed: is less than $5 \%$ of the inlet pressure. The kinetic measurements, were made both under steady state: and transient conditions. Sample chambers, immediately in the reactor ends are connected via capillaries to the online mass spectrometer for real time: analysis. The gas sampling comprises of 1/32" piping, a quick acting Helium operated (Helium supply to high speed assembly on actuator) 4 ports. Valco sampling valive, and 3-way Valco sampling valve to allow gas samples into the mass spectrometer. The total flow rate of the gas through the reactor was kept constant at high velocity in order to avoid the mass transfer limitation.

The experimental procedure for the seloctive oxidation of ammonia can be described as follows. Firstly, the water condenser for cooling down the off-gas starts running. During the reactor heating up by the use of the fluidized sand bath heater into the experimental reaction temperature, Helium flows through in a unidirectional flow. Oxygen at certain concentration is then introduced into the reactor when the reactor temperature has been reached. Subsequently, it is followed by ammonia. The feed compositions an be set from the mass flow controllors. In this case, Helium is used as a bulk gass. The reactor products are. measured in an online analysis using mass spectrometer: When the: reaction attains the steady state condition; which is indicated by the outlet concentration profiles, experiments under flow reversal can commenoe. The flow direction is periodically reversed at every switohing: time; automatically 
conducted by the computer program. When the reactor stands by, Helium at low flow rate still flows through the reactor in order to avoid the air from outward coming into the reactor.

\section{Results and Discussion}

The temperature profiles along the reactor during the reverse flow operation are shown in Figure 5. The Tl's (104, 105, 109, and 110) exhibit the temperature indicators at discrete axial positions along the catalyst bed of the reactor, i.e. at $z=0.2,0.4,0.6$, and 0.8 , respectively. In general, the temperature profiles at all axial positions show the sinusoidal fluctuations as a function of time with narrow amplitude. The sinusoidal type of profile is caused by the control response of the

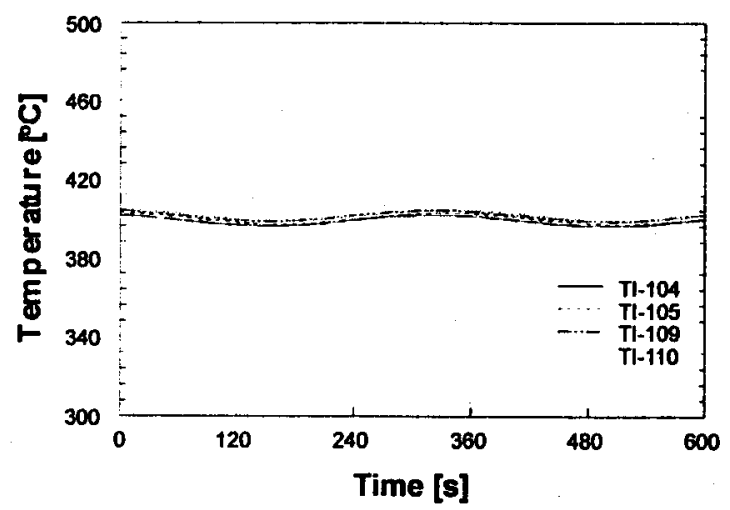

(a) fluidized sand bath heater when maintaining the reactor temperature at set-point value. The average temperature difference along the reactor axis is about $4^{\circ} \mathrm{C}$. As afore mentioned that in practice, a temperature difference along the reactor of $5^{\circ} \mathrm{C}$ is allowed to maintain nearly isothermal operation. In this respect, isothermal assumptions can still hold for the reactor modeling. Referring to Figure 5 , it is verified that the effect of switching time on the heat development can be neglected. The reactor system cannot respond to the perturbation of flow reversal and seems to behave in the regime of relaxed steady state. The influence of heat removal by the fluidized sand bath becomes much stronger than reactor heat production.

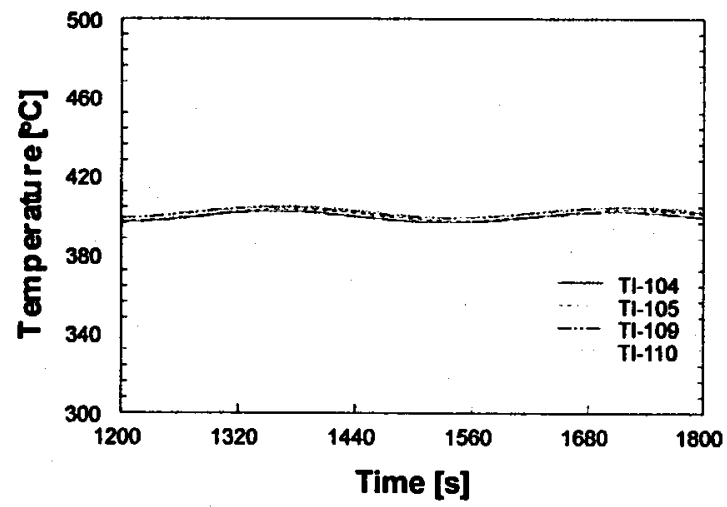

(b)

Note : The switching times are $15 \mathrm{~s}$ (a) and $2.5 \mathrm{~s}$ (b). The inlet temperature is $200^{\circ} \mathrm{C}$. The reactor Temperature

Figure 5. Temperature at Discrete Axial Positions inside The Reactor as A Function of Tịme during Reverse Flow Operation

The switching time is most important and fundamental characteristics in a reverse flow operation. Among the various parameters those usually used during the application of flow reversal, the switching time strongly influences the depth of the temperature and concentration developments inside the reactor. It also corresponds to the regimes of operation, describing how far the reactor can respond to the intentional perturbation due to flow reversal. In addition, the switching time is an engineering tool for control of temperature and concentration movements, which are developed inside the reactor. Therefore, the effect of the switching time for manipulation of the catalyst surface coverage leads to the performance of reactor conversion and product distribution.

Figure 6 shows the relative enhancement of the conversion and selectivity as a function of switching time during the normal reverse flow operation. In this case, the terms of the relative enhancement of the conversion and selectivity are defined as the difference values between the reverse flow operation and steady state operation, divided by the steady state operation (see Equations 1 and 2). In accordance with Budhi et al. (2004a), the conversion of $\mathrm{NH}_{3}$ during the regular RFO decreases significantly at shorter period of switching time. The decrease of ammonia conversion during the flow reversal is induced by an outflow of high concentration of unconverted reactant, shortly after reversing the flow direction. The effect of the concentration loss due to the flow reversal becomes a major reason in the application of reverse flow operation at miniaturized time scale, which is dedicated for manipulation of catalyst surface coverage. Such concentration loss implies that the gas has a shorter residence time in the reactor. As previously mentioned the residence time of the gas is distributed between 0 and $2 t$. In the classical operation of flow reversal for energy saving, such concentration loss shortly after every flow reversal can be neglected because the period 
of the switching time is in the order $10^{3}$ higher. The relative enhancement of the ammonia conversion during the regular RFO approaches to the steady state value when the switching time goes to the relatively higher values compared to the gas residence time. The increase of oxygen concentration in the feed may also improve slightly the ammonia conversion as shown in Figure 6b.

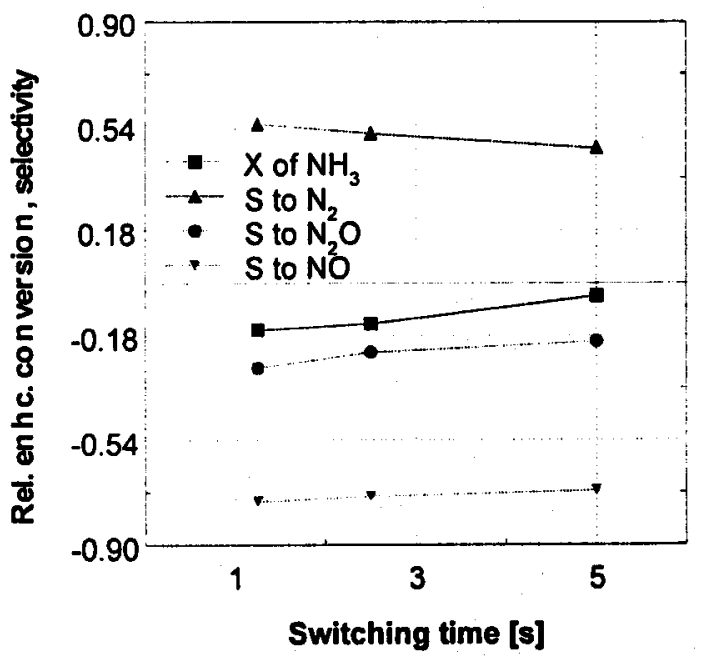

(a)

$$
\begin{aligned}
& \hat{X}=\frac{X_{R F O}-X_{S S O}}{X_{S S O}} \\
& \hat{S}=\frac{S_{R F O}-S_{S S O}}{S_{S S O}}
\end{aligned}
$$

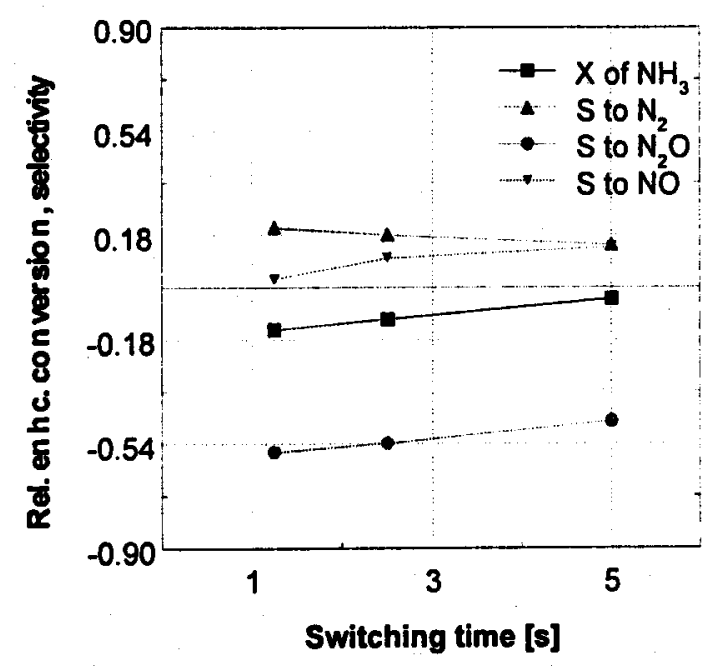

(b)

Figure 6. Relative Enhancement of The Conversion and Selectivity Differences as A Function of Switching Time during Regular Reverse Flow Operation. (a). mole ratio of $\mathrm{O}_{2}$ to $\mathrm{NH}_{3}=1$, (b). mole ratio of $\mathrm{O}_{2}$ to $\mathrm{NH}_{3}=5$. Other conditions: $T=400^{\circ} \mathrm{C}, \tau_{0}=1 \mathrm{~s}$

The influence of flow reversal on the product distributions gives the positive effect to $\mathrm{N}_{2}$ and the negative effects to $\mathrm{N}_{2} \mathrm{O}$ and NO. The selectivities towards the products drift off into two distinct effects due to the competition among the elementary reaction steps. At the operating conditions as applied in this experiment, the dedicated perturbation of flow reversal may provide more adsorbed $\mathrm{N}$ on the catalyst surface, which leads to the production of $\mathrm{N}_{2}$. In this case, the reaction-steps for the production of $\mathrm{N}_{2} \mathrm{O}$ and $\mathrm{NO}$ are suppressed and less interesting during the reaction competition. This operating condition is expected to comfortable for producing more adsorbed $\mathrm{N}$ than adsorbed $\mathrm{O}$. In fact, the adsorbed $\mathrm{O}$ is required to produce more $\mathrm{N}_{2} \mathrm{O}$ and $\mathrm{NO}$. The availability of adsorbed $\mathrm{O}$ is very potential to generate the adsorbed NO as an intermediate product, which is subsequently used for the production both $\mathrm{N}_{2} \mathrm{O}$ and NO. Detailed kinetic scheme of the ammonia oxidation on $\mathrm{Pt} / \mathrm{Al}_{2} \mathrm{O}_{3}$ can be found in Rebrov etal. (2003).

Shifting the operation regime from the dynamic into the quasi-steady state induces the tendency of the product distribution approaching the steady state value, even the response is too slow. Seemingly, the surface coverage dynamics still exists at these conditions. Therefore, the product distribution gradually changes when the switching time is shifted. When the oxygen concentration in the feed is higher, leading to the availability of the adsorbed oxygen on the catalyst surface, the selectivity towards NO increases profoundly (see Figure 6b). In contrast, the selectivity towards $\mathrm{N}_{2} \mathrm{O}$ can be suppressed accordingly.

The effect of flow reversal on conversion and selectivity becomes significant when the reactor operation is around the dynamic regime. It is necessary to emphasize once-again that reversing the flow direction induces the concentration fronts along the reactor bed, including all components adsorbed on the catalyst surface, which may influence the product distribution. The duty cycle, of course, also plays an important role for the manipulation of selectivity. It means that reactor operation under symmetric or asymmetric could result different product distributions due to the difference of the concentration fronts along the reactor. The symmetric operation means that the time period for 
switching the flow is similar for each direction (left to right and right to left). Meanwhile, the time period from left to right and vice versa is different under operation of asymmetric. The time-averaged value holds for one-full cycle, in which the formulation of the time-averaged value can be found in Budhi (2005). Figure 7 represents the experimental result for two cases: symmetric and asymmetric operations.

For both cases, regular reverse flow operation with asymmetric operation shows a lower $\mathrm{NH}_{3}$ conversion than with symmetric

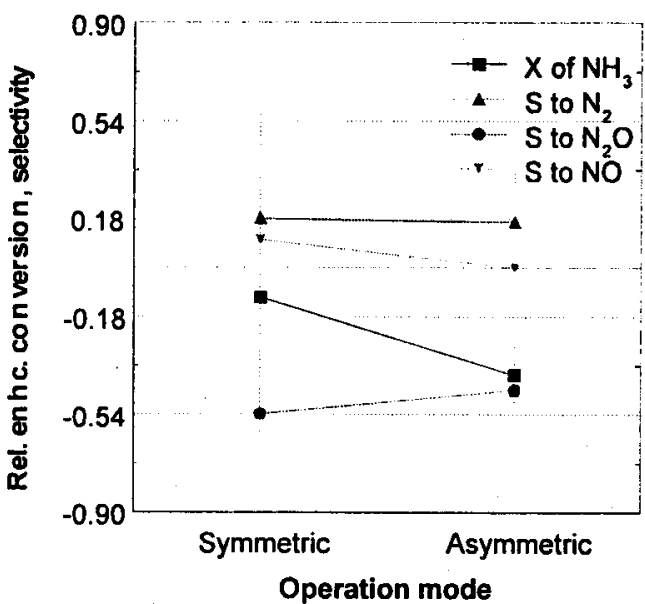

operation. This indicates that the role of the shorter time period ( $25 \%$ of the cycling time) is more significant in decreasing the conversion of $\mathrm{NH}_{3}$. The selectivity changes do not take place significantly for $\mathrm{N}_{2}$, while it does for the selectivities to $\mathrm{N}_{2} \mathrm{O}$ and NO. This indicates that flow reversal with asymmetric operation may yields the product distributions if the chosen parameters (gas residence time, switching time, and duty cycle) are in good agreement.

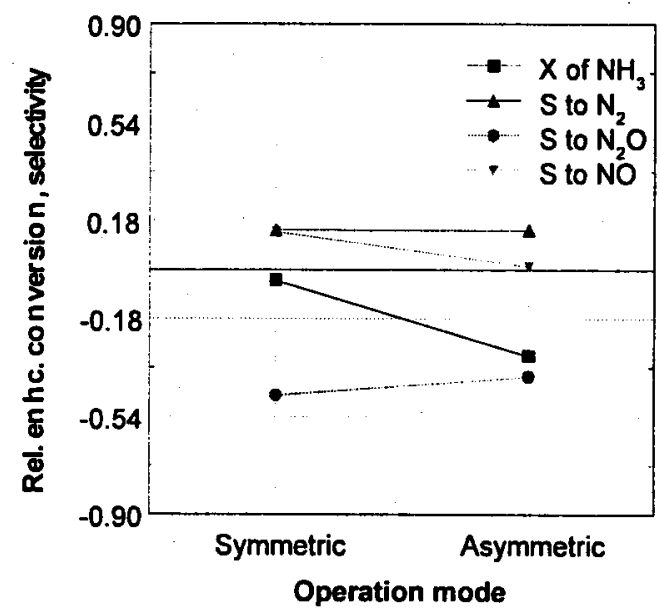

Figure 7. Relative Enhancement of The Conversion and Selectivity Differences as A Function of Switching Time during Regular Reverse Flow Operation with Symmetric and Asymmetric Operations. The time periods for forward and backward flows are $25 \%$ and $75 \%$ of the cycling time,

\section{Conclusion}

The analysis of the reverse flow reactor behavior showed that the parameter of switching time is most crucial for the generation of the dynamic system, particularly on the microscale level, i.e. catalyst surface coverage. The manipulation of catalyst surface coverage, which especially leads to the changing of selectivity, is significantly affected by the ratio of the switching time and gas residence time. The experiments show that the main factor determining the behavior of reverse flow reactor is the ratio of the switching time over the residence time. This ratio also describes the regimes of reverse flow operation.

The conversion of $\mathrm{NH}_{3}$ during the regular reverse flow operation shows lower values compared to the steady state, once-through operation. The conversion of $\mathrm{NH}_{3}$ is even worse when the reactor operation shifts to the asymmetric mode. The product distributions may change under flow reversal, depending on the operating conditions, regime of operation, and operation mode.

\section{Acknowledgements}

The financial support, provided by Novem (the Netherlands Agency for Energy and Environment), STW (Dutch Technology Foundation), and Quality for Undergraduate Education Project, Chemical Engineering Department, Institute of Technology Bandung, Indonesia, is gratefully acknowledged. Author also thanks to Prof.dr.ir. J.C. Schouten and dr.ir. J.H.B.J. Hoebink for their valuable supervision during the Ph.D. research project at Technische Universiteit Eindhoven, the Netherlands.

$$
\begin{array}{ll}
\begin{array}{l}
\text { Notation } \\
\dot{X}
\end{array} & \begin{array}{l}
\text { relative enhancement of } \\
\text { ammonia conversion }
\end{array} \\
X_{R F O}= & \begin{array}{l}
\text { time-averaged conversion of } \\
\text { ammonia during reverse flow }
\end{array} \\
& \text { operation } \\
X_{S S O}=\begin{array}{l}
\text { conversion of ammonia during } \\
\text { steady state operation }
\end{array} \\
\hat{S}=\begin{array}{l}
\text { relative enhancement of } \\
\text { selectivity }
\end{array}
\end{array}
$$




$$
\begin{array}{ll}
S_{R F O}= & \begin{array}{l}
\text { time-averaged selectivi ty during } \\
\text { reverse flow operation }
\end{array} \\
S_{S S O}= & \begin{array}{l}
\text { selectivity during steady state } \\
\text { operation }
\end{array}
\end{array}
$$

\section{Literature Cited}

[1] Bailey, J.E., (1973). "Periodic Operation of Chenical Reactors: A Review", Chemical Engineering Communication 1, 111-124

[2] Boreskov, G.K., Bunimovich, G.A., Matros, Yu.Sh., Ivanov, A.A., (1982), "Catalytic Processes Under Non-steady state Conditions. II. Switching The Direction for The Feed of The Reaction Mixture to The Catalyst Bed. Experimental Result", Kinetic and Catalysis 23(2), 402-406

[3] Boreskov, G.K., Matros, Yu.Sh., (1983), "Unsteady-state Performance of Heterogeneous Catalytic Reactions", Catalysis Review Science and Engineering 25, 551-590

[4] Budhi, Y.W., (2005), "Reverse Flow Reactor Operation for Control of Catalyst Surface Coverage", Ph.D. Dissertation, Technische Universiteit Eindhoven, the Netherlands.

[5] Budhi, Y.W., Jaree, A., Hoebink, J.H.B.J., Schouten, J.C., (2004a), "Simulation of Reverse F low Operation for Manipulation of Catalyst Surface Coverage in Tthe Selective Oxidation of Ammonia", Chemical Engineering Science 59, 41254135

[6] Budhi, Y.W., Hoebink, J.H.B.J., Schouten, J.C., (2004b), "Reverse Flow Operation with Reactor Side Feeding: Analysis, Modeling, and Simulation", Industrial and Engineering Chemistry Research 43, 69556963

[7] Bunimovich, G.A., Vernikovskaya, N.V., Strots, V.O., Balzhinimaev, B.S., \& Matros, Yu. Sh,. (1995), "SO, Oxidation in A Reverse Flow Reactor: Influence of A Vanadium Catalyst Dynamic Properties", Chemical Engineering Science, 50, 4, 565580

[8] Cittadini, M., Vanni, M., Barresi, A.A., Baldi, G., (2001), "Reverse-flow Catalytic Burners: Response to Periodical Variations in The Feed". Chemical Engineering Science 56, 1443-1449

[9] Douglas, J.M., Rippin, D.W.T., (1966), "Unsteady State Process Operation", Chemical Engineering Science 21, 305315
[10] Ferreira, R.Q., Costa, C.A., Masetti, S., (1999), "Reverse-flow Reactor for A Selective Oxidation Process", Chemical Engineering Science 54,4615-4627

[11] Matros, Yu. Sh., (1990), "Performance of Catalytic Processes under Unsteady Conditions", Chem. Eng. Sci. , 45, 2097

[12] Matros, Yu.Sh., (1989), "Catalytic Processes under Unsteady-state Conditions", Stud. Surf. Sci. Catal. 43. Amsterdam: Elsevier

[13] Matros, Yu. Sh., Bunimovich, G. A., (1996), "Reverse-flow Operation in Fixed Bed Catalytic Reactors", Catalysis Review Science and Engineering 38, 1-68

[14] Nieken, U., Kolios, G., Eigenberger, G., (1994), "Fixed-bed Reactors with Periodic Flow Reversal: Experimental Results forCatalytic Combustion, Catalysis Today 20,335-350

[15] Rebrov, E.V., de Croon, M.H.J.M., Schouten, J.C., (2002), "Development of The Kinetic Model of Platinum Catalyzed Ammonia Oxidation in A Microreactor", Chemical Engineering Journal 90, 61-76

[16] Salinger, A.G., \& Eigenberger, G. (1996), "The Direct Calculation of Periodic States of The Reverse Flow Reactor I. Methodology and Propane Combustion Results", Chemical Engineering Science, $51,4903-4913$

[17] Silveston, P.L., (1998), "Composition Modulation of Catalytic Reactors", Ontario, Canada: Gordon and Breach

[18] Silveston, P.L., Hudgins, R.R., Renken, A., (1995), "Periodic Operation of Catalytic Reactors - Introduction and Overview", Catalysis Today 25, 91-112

[19] Somani, M., Viswanath, S. Khinast, J., Luss, D., (1997), Chem. Eng. Sci., 52, 2483

[20] Stankiewicz, A., Moulijn, J., (2004), "ReEngineering the Chemical Processing Plant: Process Intensification", Marcel Dekker Inc., New York

[21] van Sint Annaland, Scholts, H.A.R, Kuipers, J.A.M., van Swaaij, W.P.M., (2002), "A Novel Reverse Fow Reactor Coupling Endothermic and Exothermic Reactions. Part I: Comparison of Reactor Configurations for Irreversible Endothermic Reactions, Chemical Engineering Science 57, 833-854

[22] Zukowski \& Berezowski, 2000 